\author{
Contatos \\ UFF - Campus do Gragoatá \\ Rua Prof. Marcos Waldemar de Freitas Reis \\ Bloco O - sala 507 \\ 24210-201 - Niterói - Rio de Janeiro \\ deniserollemberg@uol.com.br \\ UFRN \\ Av. Senador Salgado Filho, 3000 \\ 59072-970 - Natal - Rio Grande do Norte \\ rvainfas@terra.com.br
}

\section{HISTORIADORES FRANCESES NA ZONA CINZENTA: LEMBRANÇAS DA GUERRA}

\section{Denise Rollemberg*}

Universidade Federal Fluminense

Rio de Janeiro - Rio de Janeiro - Brasil

\section{Ronaldo Vainfas*}

Universidade Federal do Rio Grande do Norte Natal - Rio Grande do Norte - Brasil

\title{
Resumo
}

Este artigo analisa as lembranças de alguns historiadores franceses que viveram na França ocupada pelos alemães e, no pós-1945, construíram suas carreiras, especialmente na chamada Nova História francesa. A pesquisa está baseada em ensaios de ego-história, autobiografias e entrevistas que os autores selecionados produziram a partir de finais dos anos 1980, ou seja, quase 40 anos após o fim da guerra. O estudo tem como objetivo demonstrar, em primeiro lugar, que tais lembranças se inserem, de uma forma ou de outra, na memória construída na França do pós-guerra, influenciadas pelo mito da Resistência que o revisionismo historiográfico francês tem desconstruído desde a década de 1970. Finalmente, o artigo argumenta que a maioria dos autores selecionados, quando jovem, viveu no que Pierre Laborie chamou de zona cinzenta, inspirado na obra de Primo Levi.

\section{Palavras-chave}

Memória - Resistência francesa - Nova História - ocupação alemã da França Vichy - zona cinzenta.

* Doutora em História Social pela Universidade Federal Fluminense. Professora do Departamento de História e do Programa de Pós-Graduação em História da mesma universidade.

${ }^{* *}$ Doutor pelo Programa de Pós-Graduação em História Social da Faculdade de Filosofia, Letras e Ciências Humanas da Universidade de São Paulo. Professor visitante do Departamento de História e Programa de Pós-Graduação da Universidade Federal do Rio Grande do Norte. Membro dos Programas de Pós-Graduação da Faculdade de Formação de Professores, Universidade do Estado do Rio de Janeiro e da Universidade Federal Fluminense. 


\author{
Contacts \\ UFF - Campus do Gragoatá \\ Rua Prof. Marcos Waldemar de Freitas Reis \\ Bloco O - sala 507 \\ 24210-201 - Niterói - Rio de Janeiro \\ deniserollemberg@uol.com.br \\ UFRN \\ Av. Senador Salgado Filho, 3000 \\ 59072-970 - Natal - Rio Grande do Norte \\ rvainfas@terra.com.br
}

\section{FRENCH HISTORIANS IN GRAY ZONE: REMEMBRANCES OF THE WAR}

\author{
Denise Rollemberg
}

Universidade Federal Fluminense

Rio de Janeiro - Rio de Janeiro - Brazil

\section{Ronaldo Vainfas}

Universidade Federal do Rio Grande do Norte

Natal - Rio Grande do Norte - Brazil

\begin{abstract}
This article analyzes the remembrances of some French historians who lived in German-occupied France and, in the post-1945, built their careers, especially in the so-called New French History. The survey is based on Ego history essays, autobiographies and interviews that the selected authors produced from the late 1980s, that means, almost 40 years after the end of the war. The study aims to demonstrate, first, that these remembrances are inserted, in one way or another, in the memory built in France in the post-war period, influenced by the Resistance mith that the French historiographical revisionism has deconstructed since the 1970s. Finally, the article argues that most of the selected authors, when young, lived in what Pierre Laborie has called gray zone, inspired by the work of Primo Levi.
\end{abstract}

\title{
Keywords
}

Memory - French Resistance - New History - German-occupied France - Vichy - gray zone. 
História ciência do Homem, ciência do passado humano. E, não, de modo algum ciência das coisas ou dos conceitos. FEBVRE, Lucien. Combates pela história, 1952.

\section{I - Historiadores sob vigilância $\mathcal{E}$ historiadores em xeque}

"Historiens sous haute surveillance", eis o título de um instigante artigo de Pierre Laborie, publicado em 1994, no qual expôs os obstáculos enfrentados por uma então nova historiografia sobre a resistência francesa à ocupação alemã. Uma historiografia que pôs em xeque a ideia de que a maior parte dos franceses resistiu à ocupação alemã desde 1940, com exceção dos simpatizantes do regime de Vichy, considerados como uma minoria oportunista encrustada em um Estado fantoche - e colaborador - do ocupante alemão. ${ }^{1}$

O revisionismo dos historiadores mencionado por Laborie resultou, em certa medida, do impacto causado pelo documentário Le chagrin et la pitié (A tristeza e a piedade), lançado em 1971 por Marcel Orphüls, e, em seguida, pelo livro do norte-americano Robert O. Paxton, Vichy France, publicado em 1972 e traduzido para o francês no ano seguinte.

Trataremos deste impacto no momento devido, mas vale, por ora, mencionar que o documentário de Orphüls e o livro de Paxton sugeriram, de diversas maneiras, que a maioria dos franceses colaborou com os alemães e somente uma ínfima minoria resistiu e, mesmo assim, somente a partir de 1942. A memória oficial da Resistência, construída a partir da libertação de Paris, De Gaulle à frente, não só foi derrubada como invertida. Os historiadores que, dali em diante, se dedicaram ao estudo do tema, tentaram por os pingos nos is. Nem resistência total nem colaboracionismo absoluto. Ainda assim, pois implicava uma autêntica cirurgia na história e na memória oficial da França - estreitamente ligadas nesta altura - tal revisionismo foi mal visto no stablishment historiográfico francês.

No caso dos historiadores, tocar neste ponto implicava, antes de tudo, pôr em xeque a figura de Marc Bloch, cofundador do movimento dos Annales e membro da Resistência fuzilado pelos alemães em 1944. Um mito cujo arauto foi ninguém menos do que Lucien Febvre, autor de "Marc Bloch: de l'histoire au martyre", publicado nos Annales logo em 1945. A questão nele

1 LABORIE, Pierre. Historiens sous haute surveillance. Esprit, n. 198, 1994, p. 36-49. 
levantada por Febvre poderia se resumir na seguinte pergunta: é possível separar o Marc Bloch historiador do Marc Bloch resistente? A resposta de Febvre é um bordão recitado por meio de fórmulas diversas: Bloch sempre foi "le même" Bloch; "non, pas de deux Bloch", "jamais deux Bloch". Eis o modelo de historiador, perfeitamente adequado à memória oficial gaullista da França enfim libertada.

Fernand Braudel, herdeiro de Febvre na liderança da historiografia francesa, também pôde preencher, mutatis mutandis, o lugar mitológico de Bloch, pois lutara na guerra e ficou anos cativo dos alemães entre 1940 e 1945. Mas a liderança de Braudel, na altura em que o mito da Resistência foi posto em xeque, já estava em declínio, ele mesmo aposentado em 1969. Não era, porém, o caso do que Peter Burke chamou de "a terceira geração dos Annales", ${ }^{2}$ então empenhados em uma nova revolução historiográfica conhecida como Nova História.

Foi por pouco que os estudos revisionistas sobre a França ocupada, divulgados nos anos 1980, não coincidiram com o lançamento da Nova História pós-braudeliana, tomando como marco dela a coletânea Faire de l'histoire, ${ }^{3}$ organizada por Jacques Le Goff e Pierre Nora em 1974, dois expoentes da historiografia francesa na segunda metade do século XX. O livro de Robert O. Paxton havia saído em francês um ano antes; os historiadores franceses do Tempo Presente apenas começavam os seus estudos dos comportamentos sociais dos franceses em face da ocupação alemã.

Em todo caso, se os historiadores revisionistas da França ocupada estiveram sob haute surveillance nos anos 1980-1990, pois desafiavam a memória oficial, as estrelas da autocelebrada Nova História se viram, quando menos, em situação desconfortável, com a desconstrução da memória oficial sobre a Resistência. Afinal, a guerra também marcou a vida de vários historiadores aclamados nos anos 1970 como expoentes da Nova História. Nenhum deles conheceu Marc Bloch, é verdade; alguns conheceram Febvre; muitos privaram do convívio com Braudel. Eram homens que, nos anos 1930, ainda cursavam o liceu (nível médio) e, nos anos 1940, iniciavam a sua formação universitária. Tornaram-se historiadores de ponta.

Onde eles estavam e o que fizeram durante a guerra?

Vamos, aqui, recuperar a trajetória de alguns deles, priorizando os que se destacaram na chamada "terceira geração" - ou nela se inseriram a posterio-

\footnotetext{
2 BURKE, Peter. A Revolução Francesa da historiografia: a Escola dos Annales. São Paulo: Unesp, 1991, p. 81.

3 LE GOFF, Jacques \& NORA, Pierre (org.). Faire de l'histoire. Paris: Gallimard, 1974.
} 
ri. A base documental reside nos relatos publicados nos Ensaios de ego-história, ${ }^{4}$ publicados em 1987, obra que ao menos esboçou um novo gênero historiográfico, no qual o sujeito historiador seria, ao mesmo tempo, o objeto da investigação, produzindo um texto de história sobre si mesmo, um memorial científico. No caso de alguns historiadores que não participaram da coletânea - cuja trajetória consideramos essencial para o argumento - ou que nela ofereceram depoimentos lacônicos sobre os anos da guerra, recorremos a autobiografias e entrevistas. Ensaios de ego-história, autobiografias e entrevistas são tipos diferentes de discurso. Estamos cientes desta diversidade. Mas vamos fazer tabula rasa dessas diferenças no campo documental em favor do resgate da memória individual que, seja por que meio for, ofereça evidências relevantes para o nosso problema. Trata-se de uma escolha metodológica.

\section{Memória construída sobre a Resistência: Jacques Le Goff como referência}

Para começar o escrutínio, escolhemos Jacques Le Goff (1924-2014). Medievalista consagrado, quase um discípulo de Bloch, embora jamais o tenha conhecido pessoalmente. Um grande historiador cujo nome ficou muito associado à história das mentalidades, por ter sido o autor do artigo que trata do campo em Faire de l'histoire.

Le Goff viveu a guerra como muitos de sua geração. Como disse François Furet em uma entrevista: “o que temos em comum é que fizemos 20 anos nos anos que se seguiram à Segunda Guerra Mundial. Vivemos o fim da guerra como adolescentes, e muitos de nós estivemos na Resistência". ${ }^{5}$

Em 1940, Jacques era um adolescente de 16 anos, perto de concluir o liceu. Foi neste ano que a França foi invadida pela Alemanha, entre maio e junho. Le Goff recorda que, em maio deste ano, Toulon ficou ameaçada de sofrer bombardeios italianos, aos quais chamou de pseudobombardeios, ${ }^{6}$ talvez porque não chegaram a se realizar neste mês. Como seu pai não podia descer aos abrigos antiaéreos por razões de saúde, foi aconselhado pelo médico a deixar a cidade. Parentes da família ofereceram uma casa à beira do lago

\footnotetext{
4 NORA, Pierre (org.). Essais d'ego-histoire. Paris: Gallimard, 1987.

5 CAMARGO, Aspásia. O historiador e a história: um relato de François Furet. Estudos Históricos, vol. 1, n. 1, Rio de Janeiro: FGV, 1988, p. 143-161.

6 No original, "En mai 1940, les Italiens viennent se livrer à de pseudobombardements au-dessus de Toulon". LE GOFF, Jacques. L'appétit de l'histoire. In: NORA, Pierre (org.). Essais d'ego-histoire. Paris: Gallimard, 1987, p. 202.
} 
Thau, nas cercanias de Sète. Le Goff conta que a maior parte de maio e junho de 1940 ele passou ali.

Sem perceber ao certo a envergadura daqueles episódios, afirma que foi na praça de Oeuf que ouviu, pelos alto-falantes, o discurso no qual o marechal Pétain explicou o pedido de trégua - reconhecendo a derrota militar francesa. Pétain se tornara, então, chefe do governo francês refugiado em Bordeaux. Lembra que, no dia seguinte, ouviu, por acaso, uma parte do discurso do general de Gaulle, concitando os franceses a resistir em nome da França. Também por acaso, "indo a um barbeiro de Sète", soube que a frota francesa havia sido bombardeada pela inglesa em Mers el-Kébir.7

As lembranças do jovem Le Goff sobre os primeiros momentos da guerra são nebulosas, contrastando com a exímia precisão factual do historiador. Mistura um fato da guerra (o risco de bombardeio de Toulon) com um fato privado (a saúde do pai) para explicar a fuga da família para Sète. O bombardeio ou perigo de bombardeio de Toulon não seria razão suficiente para a família deixar a cidade? Por que não relacionar a sua própria experiência familiar com a de milhões de franceses que, com o avanço dos alemães, partiram com desespero para o sul do país? A pergunta vale porque as lembranças de Le Goff só até certo ponto podem ser consideradas apenas como "lembranças de velhos": ${ }^{8}$ uma reconstrução do próprio passado a partir do presente, uma ressignificação da própria vida e do reconhecimento de si. Isto porque, em nosso caso, trata-se, em parte, de depoimentos escritos e de lembranças de historiadores - e não quaisquer velhos - empenhados em alinhavar que aspiram a um subgênero historiográfico: a ego-história.

A ego-história, vale dizer, é um gênero que, por si mesmo, mescla história e memória. O autor é sempre um historiador de ofício que produz uma fonte calcada em sua memória individual. Como considerar tais textos: memória ou história? Impossível separar. A confusão epistemológica e metodológica é inerente a este gênero de narrativa. Objeto e sujeito se entrelaçam. O sujeito - não esqueçamos - é historiador veterano; o objeto é a memória que constrói dele mesmo. A crítica deve se afinar, jamais recuar.

\footnotetext{
Mers el-Kébir era uma base francesa no Mediterrâneo (golfo de Oran), Argélia. Em 3/7/1940, temendo que a esquadra francesa a passasse ao controle da Alemanha, os britânicos exigiram a rendição dos franceses. Como os franceses não se entregaram, a esquadra britânica atacou, resultando em 1.300 mortos.

${ }^{8}$ BOSI, Ecléa. Memória e sociedade: lembranças de velhos. 2 volumes. São Paulo: Edusc, 1987.
} 
Em todo caso, Le Goff fez questão de externar ferrenha oposição à ocupação alemã e ao regime de Vichy. ${ }^{9}$ Conta que, em 1941, teve o dissabor de desfilar diante do marechal Pétain, em $1^{\circ}$ de maio, ainda como estudante do liceu: "tive a veleidade de recusar; fui dissuadido, para minha grande vergonha, por dois colegas musculados".10 A este fato, Le Goff acrescenta que, mais tarde, soube que "esse pequeno ato de rebelião" fora registrado nos arquivos de regime, juntamente com a recusa de seu pai de servir à Legião. ${ }^{11}$ Por tal motivo, quando foi concluir o bacharelado, em Marselha, não pôde se beneficiar da gratuidade concedida aos filhos de professores do liceu.

Le Goff insinua que foi um opositor do regime francês desde a juventude, embora a família tenha regressado a Toulon pouco depois do armistício de 1940. O tema da resistência só vem à luz no contexto da invasão alemã de Vichy no final de 1942. ${ }^{12}$ Entre as duas datas, tudo indica que a família de Le Goff se ajustou à nova ordem.

Mas ele conta que se engajou na Resistência, ainda que acanhadamente. Uma resistência de que ouvira dizer até que, por acaso, no verão de 1941, compareceu a uma reunião, em Marselha, convidado por um amigo, identificado não pelo nome, senão como o "o padre de Lubac, o futuro cardeal". ${ }^{3}$

Le Goff é cuidadoso, nesta altura do depoimento, evitando atribuir-se o papel de militante em armas. Admite que não chegou a ingressar na Resistência em 1941, seja "por falta de coragem", seja pela oposição da mãe. ${ }^{14}$ Menciona que adensou seus contatos com os resistentes quando, acometido de uma pleurisia, ${ }^{15}$ foi descansar nos Alpes. Informação nebulosa porque, páginas antes, Le Goff escreve que foi para a região um dia depois do afundamento

\footnotetext{
9 Instituído a partir do armistício entre França e Alemanha em 1940. Governado pelo marechal Philippe Pétain, herói da Primeira Guerra Mundial, o regime tornou-se colaborador da ocupação alemã.

${ }^{10}$ LE GOFF, Jacques. L'appétit de l'histoire, op. cit., 1987, p. 204.

${ }^{11}$ Em julho de 1941, grupos colaboracionistas criaram a Legião dos Voluntários Franceses contra o Bolchevismo.

${ }^{12}$ Este anti-vichysmo precoce de Le Goff só rivaliza, em seu relato, com o entusiasmo que diz ter sentido pela Frente Popular, quando tinha apenas 12 anos de idade: "Je me suis rangé résolument du cotê du Front Populaire, est-besoin de le dire?". LE GOFF, Jacques. L'appétit de l'histoire, op. cit., 1987, p. 201.

${ }^{13}$ Henri de Lubac (1886-1991) foi um jesuíta que atuou na Resistência. Alcançou o cardinalato em 1983.

${ }^{14}$ Acrescenta que, por mais que sua mãe fosse anti-vichysta, tinha a atitude de muitas mães em relação ao filho único. LE GOFF, Jacques. L'appétit de l'histoire, op. cit., 1987, p. 204.

15 Inflamação nos tecidos que revestem os pulmões (pleuras).
} 
da frota francesa ancorada em Toulon. ${ }^{16}$ Alguma relação entre a mudança para os Alpes e o episódio citado? Não, Le Goff não faz qualquer menção. Lembra, porém, que somente aderiu à Resistência no outono de 1943, quando foi convocado para o Service du Travail Obligatoire (STO) na Alemanha. ${ }^{17}$ Juntou-se ao que qualifica de pseudorresistência, mais do que a "uma verdadeira resistência", palavras dele. Por que a qualificação de pseudorresistência? Segundo Le Goff, porque a função essencial de seu grupo "era receber armas e medicamentos lançados de paraquedas pelos ingleses na montanha". ${ }^{18}$ Seja como for, o grupo em que atuava acabou por cindir-se, escreve Jacques Le Goff, ficando ele na facção "mais de inspiração socialista (e incluía um número importante de judeus)"; a outra facção, mais militarizada, se compunha de oficiais e se inclinava à direita.

A narrativa de sua adesão à Resistência dá exemplo de como a memória individual sobre a experiência vivida pode ser deliberadamente moldada em valores extemporâneos. Como fonte de informação está, portanto, sujeita à crítica do historiador. Neste caso, Le Goff constrói sua experiência na guerra mesclando fatos casuais e conceitos anódinos (pseudobombardeios, pseudorresistência). As lacunas factuais são intrigantes, porque se trata de um grande historiador e não de um depoente qualquer daqueles fatos remotos. Dois exemplos marcantes: ele não identifica o grupo ao qual aderiu como resistente; prefere falar em "região alpina" em geral, sem citar Vercors, que foi o nicho da resistência francesa nos Alpes, uma espécie de La Rochele no combate à ocupação alemã.

O conceito de pseudorresistência tem a ver com o esforço de minoração que o autor fez de seu passado resistente, assim como a "falta de coragem" que atribuiu a si mesmo em 1941, quando evitou engajar-se. Estranha qualificação (ou desqualificação) de seu grupo, pois receber armas e medicamentos ingleses na montanha podia ser tarefa perigosíssima, como se sabe. Dificilmente encontraremos imprecisões deste tipo na vasta obra historiográfica do autor.

Uma análise crítica do percurso do jovem Le Goff durante a ocupação, segundo o seu próprio relato, poderia se resumir a três etapas: medo em face do avanço alemão em 1940, como sentiu a imensa maioria da população

\footnotetext{
${ }^{16}$ Episódio conhecido como o afundamento da frota de Toulon, em 28/11/1942, executada pelos próprios almirantes franceses, para evitar que os navios caíssem em poder dos alemães.

17 O STO consistiu na requisição de trabalhadores franceses pelo ocupante, entre junho de 1942 a julho de 1944, para trabalhar na Alemanha. Mas foi instituído pelo governo de Vichy.

${ }^{18}$ LE GOFF, Jacques. L'appétit de l'histoire, op. cit. , 1987, p.205.
} 
francesa; acomodação ao regime de Vichy, tempo em que se dedicou basicamente aos estudos; a recusa de servir ao STO, do que derivou a busca de refúgio nas montanhas e a aproximação com os resistentes. É o que se pode extrair, com alguma consistência, do relato do autor sobre o assunto.

A narrativa hesitante sobre a sua participação na Resistência cede lugar a afirmações contundentes, quando Le Goff expõe a sua opinião sobre o marechal Pétain e o regime de Vichy em particular, sobretudo quanto à perseguição aos judeus na França. Conta, entre outros fatos, que viu de perto o êxodo de famílias que, para fugir da perseguição antissemita de Vichy, escondiam-se nas montanhas, relacionando este horror ao "forte sentimento de aversão pela ignomínia do regime de Vichy". ${ }^{19}$

Opinião genérica, que bem pode ter sido a da maioria dos franceses, no imediato pós-guerra, exceto quanto à condenação do antissemitismo vichysta, questão que só veio à tona no país a partir dos anos 1960. Mas qual francês ousaria defender Pétain nos anos 1980? Entre os historiadores, então, qual deles ousaria relativizar o colaboracionismo do regime liderado por Pétain? Philippe Pétain, que fora herói sacralizado na memória oficial do país do entre-guerras, tornou-se o maior vilão da história francesa no século XX. Le Goff foi nesta onda, apesar de ser historiador consolidado na altura em que escreveu as suas lembranças, além de possuir farta experiência pessoal e familiar sobre o tempo de Vichy.

A qual regime de Vichy e a qual Pétain se referiu Le Goff neste depoimento? Ao Pétain de 1940, celebrado como o salvador da pátria por acabar, por meio do armistício, com os bombardeios alemães sobre a população civil? Não deve ter sido este Pétain de 1940 que Le Goff condenou em seu relato, senão o do pós-guerra. Vale conjecturar se a mãe de Jacques, católica devota, foi sempre anti-vichysta, como ele sugeriu, ou simpática à ideia de uma França agrária e católica, como pregava o regime com seu programa de revolução nacional.

Conjecturas à parte, o Pétain execrado por Le Goff não é, certamente, o Pétain de 1940, senão o da memória oficial em 1944, após a libertação de Paris pelos Aliados. Memória gaullista. Jacques Le Goff não dá detalhes de seu anti-vichysmo ou anti-pétainismo. Trata o assunto por alto e, ao concluir sua experiência na guerra, afirma: "eu não a vivi senão marginalmente, e sem marcas profundas". ${ }^{20}$

\footnotetext{
${ }^{19}$ Idem.

${ }^{20}$ LE GOFF, Jacques. L'appétit de l'histoire, op. cit., 1987, p. 206.
} 


\section{II - A geração de Le Goff no tempo da ocupação alemã}

A dificuldade de Le Goff para tratar o período da ocupação, sendo ele historiador, longe está de ser exclusiva dele. Ela foi típica dos franceses em geral, de todas as classes e ofícios, que viveram esta experiência crucial no século XX.

Quanto aos historiadores, considerando alguns da terceira geração dos Annales - e obviamente excluindo os especialistas no tema -, as lembranças da guerra registradas em textos autobiográficos ou em entrevistas, confirmam o mal-estar de quase todos, o desacerto dos testemunhos, as hesitações.

\section{François Furet, resistente de última hora}

Um brevíssimo panorama deste quadro pode muito bem começar com François Furet, grande historiador da Revolução Francesa, o mesmo que relacionou a sua geração ao tempo da guerra, quando todos eram jovens de cerca de vinte anos.

François Furet (1927-1997) dá o tom dos historiadores franceses enquanto memorialistas da ocupação da França pelos alemães. Em uma entrevista a Aspásia Camargo, inclusa no número inaugural da revista Estudos Históricos (1988), Furet contou que integrou um maquis ${ }^{21}$ - o Maquis Janson. Era um jovem de dezessete anos, entre junho e setembro de 1944, quando aderiu à Resistência, pouco antes da libertação da França. Antes de "pegar em armas", François era aluno do liceu como Le Goff e conta que distribuía panfletos contra os alemães: "uma resistência de esquerda, mas não especificamente comunista".

Esta obsessão com ser ou não ser de esquerda ou comunista no tempo da Resistência, quando eram jovens, é típica de muitos historiadores franceses amadurecidos no pós-guerra. Segundo Furet:

...o que há de característico na minha geração é que efetivamente muitos de nós fomos comunistas. A geração quase como um todo era formada por pessoas de esquerda ou de extrema esquerda. Lembro que quando eu era jovem ser socialista era praticamente impensável, de tal forma isso parecia anódino. Quando se era de esquerda, era-se comunista. Lembro que quando eu me preparei para o concurso da licenciatura, o grupo de candidatos - do qual faziam parte alguns que trilharam seu caminho na história, como Le Roy, Ladurie, Agulhon, Besançon, Richet, Ozouf - era todo de comunistas. Nessa época éramos todos marxistas e filiados ao Partido Comunista. Os que não estavam no

\footnotetext{
${ }^{21}$ Maquis (um tipo de vegetação mediterrânea) foi o termo adotado para designar os grupos de resistentes que atuavam em regiões pouco povoadas, nas florestas e montanhas.
} 
Partido em geral estavam muito próximos, eram simpatizantes. A diáspora do Partido ocorreu em torno dos anos [19]55, 56, 57, ou seja, com o krutchevismo. ${ }^{22}$

Eis nova evidência dos problemas que marcam a memória individual dos historiadores franceses do pós-1945. Juízos extemporâneos. Furet simplesmente transpõe, para os anos da guerra, uma escolha política que alguns historiadores só fizeram no pós-1945, no início da carreira acadêmica. Escolha política de um comunismo stalinista. Além disso, Furet generaliza em demasia o "esquerdismo" de sua geração, omitindo nomes de contemporâneos seus que não se enquadram no modelo, embora se tenham destacado na historiografia. O próprio Le Goff, embora se visse como homem de esquerda, jamais integrou o Partido Comunista Francês - PCF nem se aproximou dele.

No entanto, à semelhança de Le Goff, Furet minimiza a sua ação na Resistência, evitando qualquer exagero ou autoglorificação. Conta que só depois do desembarque dos Aliados na Normandia, em junho de 1944, é que se "refugiou" em Berry, no interior da França, onde a "família tinha uma propriedade", e dali passou a integrar o Maquis:

Foi uma experiência muito importante para mim, embora, para falar a verdade, eu não tenha lutado realmente muito. Minha única experiência de combate foi a tomada de uma passagem de nível. Mas para um adolescente superprotegido, com uma vida sem grandes problemas, foi efetivamente um acontecimento. ${ }^{23}$

Nada disso desmerece, porém, a obra de François Furet como historiador, a exemplo de Penser la Révolution Française, publicado em 1989. Neste grande livro, muito longe de qualquer interpretação marxista, Furet simplesmente questiona o caráter revolucionário da Revolução. Não por acaso foi um dos acusados de "direitista" pelos autores de orientação marxista.

\section{Georges Duby à margem da guerra}

Historiografia à parte, muitos integrantes da geração de Furet, recordando os anos da guerra, fazem questão de dizer que participaram da Resistência, não como heróis ou protagonistas, senão como coadjuvantes. Sugerem que foram voluntários entusiasmados; declaram que foram antinazistas e anti-vichystas; admitem, porém, que lutaram pouco na guerra clandestina

${ }^{22}$ CAMARGO, Aspásia. O historiador e a história..., op. cit., 1988, p. 145.

23 Idem, p. 144. 
contra o ocupante alemão. Em boa parte das narrativas, a impressão que fica, depurada das idealizações, é a de que eles, quando jovens, somente aderiram à Resistência na última hora ou para escapar do STO.

Uma exceção digna de registro é Georges Duby (1919-1996), mais velho que Le Goff e também protagonista da renovação dos estudos medievais dedicados à história das mentalidades. Na autobiografia de historiador publicada em 1991, Duby praticamente não mencionou a guerra. ${ }^{24}$ No ensaio de ego-história publicado em 1987, sim, chegou a fazer breves comentários. Mas o título do ensaio, "O prazer do historiador", já diz tudo. Duby se dedica quase exclusivamente à sua trajetória no métier, de maneira brilhante, como se sua vida se resumisse à carreira. Nada de política ou ideologia.

Seja como for, ele oferece alguns fatos de sua experiência naqueles anos. ${ }^{25}$ Menciona que estava para terminar o liceu, em Lyon, quando sua classe foi mobilizada para atuar na retaguarda do front. Não chegou a combater, mas atuou na defesa de um dos fortes de Grenoble, carregando munição para as metralhadoras. Mais não fez, nem diz que fez. Admite que odiava a guerra e considerava uma suprema injustiça dar sua vida por uma causa perdida. Não constrói uma autoimagem de patriota. Após o armistício, regressou a Lyon para seguir os estudos. Formou-se e iniciou a carreira docente com a entrada do exército alemão na zona livre de Vichy. Não diz quando, acrescentando que logo se viu ameaçado pelo famigerado STO. O jovem Georges escondeu-se, evitou o recrutamento e, mais que isto, conseguiu documentos falsos que lhe permitiram visitar Paris em 1943.

Georges Duby merece ser tratado como exceção dentre os historiadores de sua geração porque, em momento algum, como muitos fizeram, sugeriu um falso patriotismo ou ligação, ainda que tênue, com organizações da Resistência. Ainda assim, a imprecisão factual contrasta com a perícia do historiador ao tratar dos episódios da história da França medieval. Onde se escondeu para escapar do STO? Como conseguiu o salvo-conduto (ausweis) que lhe permitiu ir de Lyon a Paris? Georges Duby não se fez de herói, é certo. Mas o seu depoimento é lacunoso sobre episódios de grande interesse para o cotidiano da guerra, mais do que sobre a sua atuação diante da ocupação.

\footnotetext{
${ }^{24}$ DUBY, Georges. A historia continua. Rio de Janeiro: Jorge Zahar Editor, 1993.

${ }^{25}$ DUBY, Georges. Le plaisir de l'historien. In: NORA, Pierre (org.). Essais d'Ego-histoire.., op. cit., p. 121-123.
} 


\section{Pierre Chaunu se reinventa: um "quase resistente"}

Entre os historiadores franceses que pisam em ovos para dizer onde estavam e como atuaram durante a ocupação alemã, Pierre Chaunu (19232009) oferece exemplo precioso. Antes de tudo porque, como se sabe, foi um dos grandes discípulos de Fernand Braudel (1902-1985), o delfim da historiografia francesa nos últimos anos de Lucien Febvre. Braudel dispensa apresentações bibliográficas. Chaunu admite que somente alcançou seus temas de investigação, referências teóricas, problemáticas, fontes e tudo mais quando encontrou Braudel, já historiador.

Mas, o que dizer do jovem Pierre Chaunu no tempo da guerra e da ocupação? Chaunu, um ano mais novo que Le Goff, não consta da lista que Furet fez dos historiadores que viveram a ocupação na juventude. Pierre Chaunu era filho de ferroviário e não conheceu a mãe, falecida quando ainda era bebê. Seu texto de ego-história, por isso mesmo, tem título sinistro: "O filho da morta". Criado pelo tio, oficial do exército francês a quem venerava, descrevendo-o como "mais que pai, meu companheiro, o irmão, o guia, o confidente, a minha memória, o meu saber, o meu tudo (...)". ${ }^{26}$

Antes de tratar propriamente de sua atuação na guerra, Chaunu oferece, com esmero, diversos trechos literários. Comenta que o tio, um homem das Luzes, era militar que não gostava da guerra; recorda de como ele mesmo, Chaunu, oscilou entre seguir a carreira militar, a de historiador ou a de médico; de como se encantou pela história nos idos de 1934, ao ouvir uma conferência sobre o antigo Egito...

Ao tratar do contexto político dos anos 1930, realça o impacto que sofreu quando a população do Sarre, na fronteira franco-alemã (a $40 \mathrm{~km}$ de Metz, onde vivia), votou em peso pela integração da região ao Reich alemão, em 1935, em detrimento da França. ${ }^{27}$ Chaunu se insinua como um grande patriota.

Na mesma altura, como que a organizar o sentido de sua narrativa, sublinha que Metz, onde cresceu, era a "grande cidade judia da França" e seus "colegas israelitas", falantes de alemão, sabiam o perigo que corriam, quando ouviam notícias da Alemanha pelo rádio ainda em 1938. Em seguida, conta

\footnotetext{
${ }^{26}$ CHAUNU. Le fils de la morte. In: NORA, Pierre (org.). Essais d'ego-histoire..., op. cit., p. 68.

${ }^{27}$ Após a I Guerra Mundial, o Sarre, rica em carvão, ficou sob a jurisdição da Liga das Nações. Mas o Tratado de Versailles (1919) estabeleceu que, após quinze anos, sua população seria consultada sobre a reintegração ou não à Alemanha. No plebiscito de 1935, 90,73\% votaram pela reintegração ao então III Reich.
} 
um episódio em que se revelou contrário ao antissemitismo que grassava em Metz. Indispôs-se, ou disse tê-lo feito, com o filho de um farmacêutico que se proclamou antissemita, não disse em que ano, acrescentando não admitir "algumas zombarias antissemitas". ${ }^{28}$ Não admitia na época ou quando fez a sua narrativa? Admitia algumas ou nenhuma?

Os comentários sobre a Frente Popular e sobre a guerra civil espanhola oferecem nova evidência da narrativa incerta de Chaunu. No caso da Frente Popular, o raciocínio é tortuoso: conta que, no liceu de Metz, o grupo mais ativo da época simpatizava com a Ação Francesa ${ }^{29}$ organização de extremadireita; mas não ele, Pierre, "resolutamente republicano", seguidor da tradição familiar que venerava Poincaré, ${ }^{30}$ por tais inclinações, admite que viu, "sem prazer", a ascensão da Frente Popular. No caso da guerra civil espanhola, afirma que seu coração tendia, decididamente, pelos "heróis de Alcazar"31 - franquistas; mas sua "razão política", a partir de 1938, fez-lhe perceber que a vitória de Franco podia significar um aliança da Espanha com a Alemanha, país que mais ameaçava os franceses. ${ }^{32}$

A impressão que este depoimento sugere é a de que o autor se esforça, deliberadamente, por minorar as posições outrora assumidas, matizando as suas conexões, desculpando-se nas entrelinhas por eventuais equívocos então cometidos (pois suas posições na época tornaram-se politicamente incorretas no pós-guerra). Passado a limpo o discurso, o jovem Chaunu parecia simpatizar, no tempo do liceu, com o pensamento de direita, razão pela qual lastimou a vitória do Front Populaire e celebrou o avanço dos franquistas na Espanha, ao menos no início da guerra civil. Em todo caso, vale registrar que os episódios lembrados por Chaunu ocorreram quando ele não passava de

\footnotetext{
${ }^{28}$ No original: “...parce que je n'admets pas quelques quolibets antisémites". CHAUNU, Pierre. Le fils de la morte..., op. cit., p. 73.

${ }^{29}$ Action Française foi uma organização política criada em 1898, no contexto do affaire Dreyfus, sob a influência das ideias de Charles Maurras (1868-1952), político monarquista, escritor, jornalista, figura de destaque no movimento contra o capitão Alfred Dreyfus, de inspiração antissemita. Movimento de extrema-direita, a AF defendeu "a violência a serviço da razão", rejeitou a legalidade, sustentou um nacionalismo germanófobo, o antissemitismo e a hostilidade à democracia parlamentar.

${ }^{30}$ Raymond Poincaré (1860-1934) foi presidente da República Francesa entre 1913 e 1920. Figura destacada na III República (1870-1940), pertencia à Aliança Democrática, partido laico e liberal, que se afastou da centro-esquerda para a centro-direita nos anos 1930.

${ }^{31}$ A resistência ao cerco de Alcazar de Toledo pelas tropas republicanas, em 1936, foi celebrada como epopeia pelos franquistas.

${ }^{32}$ CHAUNU, Pierre. Le fils de la morte..., op. cit., p. 73.
} 
um menino ou rapaz de 13 anos. Quando muito, ao comentar fatos de 1938, não passava dos 15 anos. Nesta lembrança de Chaunu há muita análise para pouca idade, e nenhuma experiência, quanto mais para razão política. Os ajuizamentos políticos que Chaunu diz ter feito - se é que os fez naqueles anos - lembram, antes de tudo, a opinião política de sua família, em particular as ideias anticomunistas do tio ou dos colegas direitistas do liceu de Metz.

Finalmente, a guerra: onde estava, o que fez o jovem Chaunu? Conta que já morava na Normandia desde 1938, por exigência do pai (que reaparece na narrativa) quando a França declarou guerra à Alemanha. Sentiu este fato como uma "libertação", não diz como nem por que, embora admita que os adultos, na época, estranhavam que uma criança externasse opiniões políticas. Pierre Chaunu tinha, então, 16 anos. Não era mais criança, nem "quase adulto", como fez constar no texto memorialístico. Ao tratar da opinião dos adultos sobre as suas avaliações, dá uma deixa de que a sua maturidade era discutível. Ao julgar-se como quase adulto, executa operação contrária, sugerindo ser mais atilado do que os jovens franceses de sua idade. Autocomplacência quiçá ardilosa, depoimento inconsistente.

No seguimento do relato, conta que estava em Rouen, em 10 de maio de 1940, quando os alemães invadiram a França. Seguem-se lembranças em tom literário, a jovem caixeira que desabou em lágrimas, a esperança na inexpugnabilidade da Linha Maginot, como lhe garantira o tio, e outras mais. Daí Chaunu salta para 1942, com todas as imprecisões cronológicas possíveis, incluindo o término do liceu ("no início da guerra") e o ingresso na Sorbonne ("que funcionava quase normalmente"). Admite, enfim, que conseguiu o diploma entre junho e agosto de 1944, superando várias dificuldades: a obstrução dos trens, o desgaste dos pneus de sua bicicleta, os horários da Biblioteca Nacional, em meio à Batalha de Paris. ${ }^{33}$ Não diz nada sobre a história geral, sequer menciona o desembarque dos Aliados, exatamente em junho de 1944!

Pierre Chaunu não aderiu à Resistência, tampouco disse que o fez. Durante a guerra, conta ter se dedicado à pesquisa e, no pós-1945, após o encontro com Braudel, detalha a construção de sua carreira acadêmica. Assim, investe na fase áurea de sua vida - a produção historiográfica em alto nível e se livra do incômodo de lembrar-se da juventude: sua inclinação à la droite nos anos 1930; sua omissão política no tempo da guerra. Não cabe insistir, porém, nos desacertos do depoimento de Chaunu, historiador meticuloso,

\footnotetext{
${ }^{33}$ A Batalha de Paris, que resultou na libertação da cidade, ocorreu entre 19 e 25 de agosto de 1944.
} 
senão sublinhar a imprescindibilidade da crítica às fontes e à memória seja individual seja coletiva. Lições sugeridas por Marc Bloch que Chaunu, neste caso, preferiu não seguir.

\section{Philippe Ariès: Vichy como herança familiar}

Assim como Chaunu, Philippe Ariès (1914-1984) não se engajou em grupo algum de resistentes durante a guerra. Era dez anos mais velho do que os autores até aqui comentados. Mas pode-se dizer que ainda era bem jovem quando a França caiu frente à Alemanha. Foi recrutado para combater o inimigo com 26 anos e só não lutou porque o armistício foi assinado antes que sua unidade fosse enviada ao front.

Ariès publicou excelente autobiografia em 1980, Un historien de dimanche, traduzido no Brasil em 1994. ${ }^{34}$ Nele, além de reflexões sobre a carreira, o autor trata, com muita serenidade, da sua infância, da família, dos anos de guerra. À diferença da maioria dos colegas de geração, não faz o menor esforço para contar uma história politicamente correta.

Os ascendentes de Ariès, segundo ele mesmo, compunham o que ele qualifica de "parentela atlântica": franceses que migraram da França para a Martinica, no Caribe, para investir na economia açucareira e escravista da ilha. Um de seus avós manteve até o século XX um negócio na ilha, embora a família tenha regressado à França no início do século XX, estabelecendose em Bordeaux, depois em Blois, no centro da França (onde nasceu Philippe), finalmente em Paris após 1920. Ariès conta que, em geral, sua família era católica e monarquista, frisando que os avós, bem como sua mãe, eram católicos ultramontanos. ${ }^{35}$ Eis uma característica dos grupos sociais mais conservadores no país, gente que não sentia a menor simpatia pelos ideais da Revolução Francesa.

Apesar das dificuldades enfrentadas por uma família do Caribe francês para readaptar-se à vida na metrópole, os avôs de Philippe se reergueram. O pai formou-se em engenharia elétrica. Ariès conta que sua família escapou da crise econômica (de 1929), embora o pai não fosse rico. Pobre também não era, Philippe admite: "sem dúvida tínhamos criados, mas, além das despesas

\footnotetext{
34 ARIÈS, Philippe. Um historiador diletante. Rio de Janeiro: Bertrand Brasil, 1994.

35 O ultramontanismo surgiu na França (século XIX) e logo se espalhou pelo mundo católico. Sustentava a primazia do papado nas decisões de fé e disciplina católicas, além de combater o laicismo e o liberalismo.
} 
com a educação dos filhos, eram as férias e a cozinha os únicos luxos dessa burguesia trabalhadora. Até a guerra, tivemos cozinheiras negras que, aliás, preparavam pratos maravilhosos (...)".36

Resumindo, Philippe Ariès nasceu e cresceu no seio de família burguesa que conservava certa nostalgia do passado senhorial martinicano. Mas, como frisa o autor, era uma "burguesia trabalhadora", não um grupo parasitário de rentiers. A certa altura, diz que predominavam em sua família homens politicamente reacionários e culturalmente progressistas" ${ }^{37}$ pois apostavam na ciência e nos avanços tecnológicos.

Goste-se ou não das convicções e valores da família de Ariès, é digno de nota o desprendimento da narrativa, tratando-se de uma tradição execrada no meio acadêmico francês, mormente nas humanidades. Sua família era um exemplo dos grupos sociais que apoiaram o regime de Vichy e a revolução nacional liderada pelo Pétain. Ariès não esconde nada disso - o que "atrasou" em demasia a sua incorporação ao métier dos historiadores - ambiente de forte tendência de esquerda ou, pelo menos, leal aos ideais da Revolução Francesa e à resistência contra a ocupação alemã.

Arì̀s publicou a sua autobiografia quando as barreiras para o seu reconhecimento acadêmico já tinham caído. Não é de surpreender, portanto, que tenha escrito, então, o que escreveu sobre o passado de sua família. Reconhece que, no campo da política, a família se dividia entre a Action Française católica, reacionária - da qual Chaunu fez questão de se distanciar, e o Sillon, movimento que oferecia aos trabalhadores uma alternativa de militância católica contra a esquerda organizada. ${ }^{38}$ Nos dois casos sobressai o catolicismo antiesquerdista: o primeiro elitista, o segundo, por assim dizer, trabalhista.

Ariès não hesita em dizer que, formado em colégio jesuítico, concluiu o liceu em escola laica, ingressando no grupo Estudantes da Ação Francesa, com carteira de membro e participação ativa em reuniões periódicas. Isto ocorreu por volta de 1930 - embora Ariès não indique o ano exato. Escrevendo sobre o assunto cerca de meio século depois, Ariès explica suas opções aludindo a duas tradições que o cercavam: de um lado o tradicionalismo familiar (católico, monarquista); de outro "um elemento novo, que não me parecia novo: o nacionalismo autoritário, antidemocrático e antiparlamentarista". Análise excelente de suas escolhas políticas, arrependimento algum.

\footnotetext{
36 ARIÈS, Philippe, op. cit., p. 31.

37 Idem, p. 27.

${ }^{38}$ Movimento político fundado por Marc Sanguier (1873-1950).
} 
Em todo caso, o elemento novo que seduziu Ariès na política não resume o projeto de revolução nacional de Vichy?

Nos anos da guerra, Ariès se dedicou à pesquisa e iniciou a carreira de historiador. Viveu os anos 1940-1941 na Biblioteca Nacional de Paris. Deixou de lado a política, mas não sua vinculação in pectori à AF. Iniciou a docência em uma escola criada pelo regime de Vichy, a Escola de Quadros de Uriage. ${ }^{39}$ Demitiuse, não diz o ano, nem a razão exata, mas continuou a servir ao regime vichysta, então como pesquisador de um instituto dedicado a investigações sobre a agricultura nas regiões coloniais. Tais institutos, lembra Ariès, sobreviveram à guerra, mantendo as suas atividades durante a Quarta República (1946-1958).

Embora dedicado a investigações agronômicas, Ariès não abandonou a pesquisa histórica. Ao contrário, nela mergulhou a fundo, interessado, antes de tudo, em estudar a sociedade tradicional. Admite, sem constrangimento, a influência que recebeu da ideologia de Vichy, que apostava no regionalismo contra valores universais, o que lhe permitiu conciliar suas inquietações intelectuais com "um sentimentalismo antigo". O primeiro livro de Ariès foi publicado em 1943 - um ensaio histórico intitulado Les traditions sociales dans le pays de France. Admite, em sua autobiografia, que cada palavra do título traduz as suas preocupações na época: tradicionalismo, região, estudo da comunidade - objetos um passo acima da família e bem abaixo das organizações públicas. Ariès tangenciava, nesta altura, o que décadas depois foi valorizado pela história das mentalidades. Mas ele não apostava na imobilidade da história, como também não o fariam os historiadores da terceira geração dos Annales, senão em uma dimensão da temporalidade na qual o movimento histórico era lento. Numa palavra: a longa duração que Braudel expôs poucos anos depois em O Mediterrâneo... (1949) e teorizou em ensaio clássico de $1958 .{ }^{40}$

Historiografia e teoria da história à parte, vale questionar: Ariès foi homem de direita, vichysta na juventude? Foi sim, ele mesmo assume as suas posições. Mas, seja como for, oferece elementos para uma boa discussão, com poucas evasivas e nenhuma contrição, não obstante sua formação católica. Sem pecado, sem medo.

\footnotetext{
${ }^{99}$ École d'Uriage, como ficou conhecida, perto de Grenoble, foi a escola de formação de quadros políticos mais importante do regime de Vichy, atuando segundo o espírito da revolução nacional. Entretanto, acabou por se opor à política de colaboração defendida por Pierre Laval (1942) distanciando-se de Vichy.

${ }^{40}$ BRAUDEL, Fernand. A longa duração. In: Idem. Escritos sobre a história. São Paulo: Perspectiva, 1992, p. 41-78.
} 


\section{René Rémond: memória arquitetada}

A vida profissional de René Rémond (1919-2007) teve muitas facetas. Além de autor de obras consagradas na historiografia, com destaque para o clássico La droite en France, publicada em 1954, formou, como professor, gerações de historiadores e dedicou-se à gestão acadêmica em várias posições. Como historiador da idade contemporânea, defendeu a renovação da história política e a legitimação da história do tempo presente, o que o levou a outra atividade: analista dos processos eleitorais franceses na televisão e no rádio por 25 anos. De forte formação cristã, aspecto que considerava essencial no seu itinerário intelectual, foi membro da Juventude Estudantil Cristã (JEC) desde os 14 anos, instituição da qual participou em vários cargos ao longo da vida. ${ }^{41}$

Em seu ensaio de ego-história, publicado em 1987, pouco se referiu à Segunda Guerra Mundial, logo ele que, na condição de resistente, recebeu a Médaille de la reconnaissance française. Alude, de passagem, ao choque da derrota e da ocupação, à libertação, frisando que esses anos imprimiram "marcas decisivas" à sua geração. ${ }^{42}$ Menciona que, ao fim da guerra, recém-saído da agregação, só lhe restaram oito semanas para se preparar para assumir o cargo de professor. Partidário do catolicismo social, mas assumindo-se como conservador da ordem, opôs-se à revolução nacional, crítico das fraquezas do regime que acabava de ruir. Precisamente, sobre sua atuação na Resistência, diz:

Uma participação, embora modesta, em atividades clandestinas de resistência ensinou-me, mais do que todas as leituras, a diferença radical entre as situações ditas normais, em que a vida em sociedade é regida pelo direito e se conforma grosseiramente com as regras, e as situações de exceção e de anomalia; é a lembrança desta experiência que se revolta, por vezes, contra os julgamentos por demais simplistas que até historiadores, devido a nunca terem conhecido experiências do tipo, fazem sobre o comportamento dos franceses de então. ${ }^{43}$

Rémond parece falar mais do presente do que do próprio passado, explicitando como ninguém o ponto de observação das narrativas de memória.

\footnotetext{
${ }^{41}$ RÉMOND, René. La droite en France de 1815 à nos jours: continuité et diversité d'une tradition politique. Paris: Aubier, 1954. A partir da 4 a edição (1982), o livro ganhou o título atual, Les droites en France (AubierMontaigne). Ver MERCIER, Charles. Un itinéraire professionnel. In: JEANNENEY, Jean-Noël \& SIRINELLI, Jean-François (org.). René Rémond historien. Paris: Presses de Sciences Politiques, 2014. ${ }^{42}$ No original, "repères décisiss". RÉMOND, René, op. cit., 1987, p. 308.

${ }^{43}$ RÉMOND, René, op. cit., 1987, p. 335. Nesta citação, usamos a tradução da edição portuguesa: Ensaios de ego-história. Lisboa: Edições 1970, 1989, p. 328.
} 
Foi na entrevista concedida a Alya Aglan em 1991, editada no livro que a historiadora dedicou à história da Rede Jade-Fitzroy, organização da Resistência articulada ao serviço de inteligência da Grã-Bretanha, que esses acontecimentos apareceram com destaque. ${ }^{44}$ Nela, Rémond atuou na obtenção de informações que eram transmitidas a Londres.

Na altura em que explodiu a guerra, Rémond preparava-se para o concurso de acesso à Escola Normal Superior, ${ }^{45}$ mas foi mobilizado para o exército em 1940, servindo no regimento de alunos aspirantes em Fontenay-le-Comte. Após a derrota, integrou o exército do armistício - restrito a cem mil homens, conforme o documento de capitulação. Desmobilizado em 1941, regressou a Paris, prestou o concurso de admissão e ingressou da Escola ENS em outubro de 1942.

A narrativa de Rémond dá bem o tom do dia a dia na capital ocupada, onde o cotidiano dos habitantes podia seguir seu curso, independentemente da disposição de colaborar ou não com os alemães ou, até mesmo, de resistir. Foi assim que o jovem René conseguiu dedicar-se, simultaneamente, aos estudos na rigorosa ENS, à militância na JEC e, entre 1943 e 1945, às atividades clandestinas da Resistência.

Na entrevista a Aglan, contou que se opôs, em 1938, ao acordo de Munique, então apoiado pela maioria da opinião pública francesa; ${ }^{46}$ jamais acreditou na colaboração, ao contrário da maioria dos franceses, em sua opinião; aplaudiu as vitórias da Inglaterra na Líbia no outono de 1940 e a resistência dos gregos aos italianos. Atribuiu sua reação "patriótica e ideológica" contra o nacional-socialismo à investida alemã de dominação sobre a Europa e o mundo. Acrescentou que também não nutria qualquer simpatia pelo fascismo italiano ou pelo comunismo. Sem engajamento partidário, declarou-se um democrata liberal e pluralista, defensor da liberdade e avesso a qualquer regime autoritário. Nos anos 1930, "dependendo das questões em causa”, sentia afinidade pela direita, mas também por "certas reformas do Front Populaire", 47 equação de difícil compreensão, considerando a polarização que marcou aquele enfrentamento.

\footnotetext{
${ }^{44}$ René Rémond dit "Robert". In: AGLAN, Alya. Mémoires résistantes. Histoire du Réseau Jade-Fitzroy, 1940-1944. Paris: Éditions du Cerf, 1994. A entrevista foi concedida em 27 de junho de 1991.

${ }^{45}$ A Escola Normal Superior é uma instituição superior de ensino diretamente ligada ao Ministério do Ensino Superior e da Pesquisa Científica, reunindo a elite docente e discente da França.

${ }^{46}$ A Alemanha retomou, então, a região dos Sudetos (na Tchecoslováquia).

${ }^{47}$ RÉMOND, Réne, op. cit., 1994, p. 299 e 300.
} 
Voltando ao cotidiano da Paris ocupada e, mais precisamente, da ENS, conta que ele e outros normalistas desejavam "superar uma atitude que não era passiva, mas que não se traduzia em uma ação positiva". A chegada à escola coincidiu com a vitória em El-Alamein. ${ }^{48}$ Os internos, nos alojamentos, apertavam-se para escutar a rádio Londres. "Havia [na ENS] uma atmosfera de resistência", embora admita que "alguns [estudantes] não eram resistentes, mas, no conjunto, jamais traíram a confiança". Nesse momento, a direção da escola cabia a Jérôme Carcopino, historiador da Roma antiga, ex-ministro da Educação Nacional de Vichy, a quem Rémond qualifica de "vichista, mas patriota", buscando resgatá-lo de um passado pouco honroso no pós-guerra. Faz questão de lembrar que Carcopino deixara a pasta ministerial quando do retorno de Pierre Laval ao governo em abril de 1942.49

Esforçando-se para recuperar a atmosfera na ENS, Rémond menciona o entusiasmo dos normalistas com o sucesso das tropas aliadas e o desejo de participarem da Resistência. Fala do risco de recrutamento pelo STO, que assombrava boa parte dos jovens franceses que, para escapar, acabavam aderindo a grupos de resistência. Refere-se ao entusiasmo dos alunos, mas nada diz sobre o comportamento de professores e funcionários.

Ele mesmo diz que, no verão de 1943, pensou em juntar-se a um maquis, mas optou por voltar às aulas no outono. Foi então que, no mesmo ano, ele e um amigo (não identificado) foram encaminhados a um grupo de resistentes sobre o qual pouco sabiam. Conta que seguiam seus cursos normalmente, cumprindo as tarefas da organização, em geral burocráticas, "nas horas vagas". "Minha vida não foi interrompida, levei tudo paralelamente", esclarece ${ }^{50} \mathrm{O}$ trabalho na Resistência parece ter se tornado mais sério em fins de junho de 1944, quando ele e o amigo passaram a fazer "espionagem", recolhendo informações, identificando aviões e aeroportos auxiliares da região parisiense. Tais ações, vale lembrar, ocorreram a cerca de um mês antes da libertação de Paris. Em todo caso, René diz ter atuado na libertação da capital, sempre nas atividades de inteligência. Acrescenta, enfim, que somente após a libertação soube que atuara na Rede Jade-Fitzroy. ${ }^{51}$

\footnotetext{
${ }^{48}$ Ocorrida no Egito, entre 23/10 e 3/11/1942, a batalha marcou o início da derrota alemã no norte africano.

${ }^{49}$ RÉMOND, Réne, op. cit., 1994, p. 301.

${ }^{50}$ Idem, p. 312.

${ }^{51}$ RÉMOND, Réne, op. cit., 1994, p. 303.
} 
A narrativa de Rémond tinha, como a de outros colegas de sua geração, assuntos cruciais: Pétain, Vichy e a revolução nacional. Muitas vezes, utilizou-se da primeira pessoa do plural e do pronome indeterminado on, em francês, deixando no ar se tal ou qual opinião era dele ou da opinião pública. Neste depoimento de 1991, Rémond evitou comentar a revolução nacional do regime de Vichy. No ensaio de ego-história, de 1987, por outro lado, declarou-se contrário à revolução nacional, ancorada nos valores conservadores da França profunda, católica, antiliberal e anticomunista, tão caros à sua formação. O que teria mudado entre os dois depoimentos?

Sobre as multidões que se aglomeravam em praça pública para receber Pétain em suas viagens pelo país, avaliou:

...ele recebia um acolhimento entusiasmado, quase unânime. É difícil de interpretá-lo, pois era a ocasião para os franceses de se reencontrar entre si e de celebrar a comunidade nacional, isso não significa que se aprovava seu governo e menos ainda sua política. ${ }^{52}$

Estaria Rémond interpretando o sentimento dos franceses em geral ou falando de si? O autor não esclarece. Por meio de sujeitos indeterminados ou alusões aos "franceses", Rémond deixa entrever que, como a maioria dos franceses, aderiu aos que nutriam esperanças no marechal Pétain, o vencedor de Verdun. Os males do regime, pelo que conta, parecem ser de responsabilidade de Pierre Laval. Esta impressão vê-se reforçada quando analisamos a entrevista de 1976. Conta que, no seu regimento militar, quase todo mundo era pétainista, somente "um pequeno número era gaullista". Já no seu batalhão, onde havia boa quantidade de gaullistas, “...eles eram suspeitos por parte da segurança militar que os vigiavam".53 "Meu capitão era gaullista e eu partilhava seus sentimentos". ${ }^{54} \mathrm{O}$ capitão acabou por se reunir à Resistência e tornou-se general com os Français Libres. ${ }^{55}$ Rémond, como vimos, aguardou a desmobilização, quando voltou a Paris e retomou os estudos preparatórios para a ENS.

O conjunto de narrativas de Rémond configura um novelo de incongruências. Oferece indicações de que admirava Pétain e De Gaulle ao mesmo tempo; de que condenava o regime de Vichy, mas não propriamente a revo-

\footnotetext{
52 Idem, p. 309.

53 Idem, p. 310.

${ }^{54}$ Idem, p. 309.

${ }^{55}$ Chamam-se Français Libres todos aqueles que, atendendo ao apelo do general de Gaulle em Londres, se engajaram nas Forças Francesas Livres (FFL) ou nas organizações e movimentos de Resistência.
} 
lução nacional, tema que evitou; de que entrou para a Resistência junto com um amigo que não identifica, tampouco sabia o nome do grupo em que atuava - e logo no setor de informações. Somente atuou, para valer, depois do desembarque aliado na Normandia e pouco antes da libertação de Paris, sem abandonar o estudo para os exames da ENS. Um resistente nas "horas de folga".

\section{Marc Ferro, combatente de Lyon}

Para concluir nossa amostragem geracional, vale a pena comentar o caso de Marc Ferro, parisiense, nascido em 1924, o mesmo ano de Le Goff. Ferro, assim como Furet, não consta da lista de historiadores que escreveu texto nos ensaios d'ego-histoire, de modo que nossa base de informação reside em uma entrevista do autor, datada de 2005, para a revista Le Temps de Médias, ${ }^{56}$ conduzida por Anne-Claude Ambroise-Rendu, e no artigo de Dany Stives, publicado em 2014 em L'Humanité, periódico tradicional do Partido Comunista Francês. ${ }^{57}$

Marc Ferro, que no pós-guerra foi militante do PCF como outros Colegas de sua geração, difere dos autores até aqui comentados porque, como historiador, sempre se dedicou ao estudo da história contemporânea - e não à história medieval ou moderna. É um dos maiores especialistas franceses na história da Revolução Russa e da URSS, além de pioneiro no estudo do cinema como fonte para a pesquisa histórica.

A sua biografia também é peculiar. Ferro não descende de franceses, tampouco de família burguesa ou pequeno-burguesa, agrária ou urbana. Seu pai, Jacques, era judeu grego natural da ilha de Corfu, imigrou para a França no início do século XX, trabalhou como bancário. Marc tinha apenas seis anos de idade quando ficou órfão de pai em 1930. Foi criado pela mãe Oudia Firdmann, ucraniana de origem judaica, e pelo avô em Paris. Tinha 17 anos em 1941, quando seu avô decidiu enviá-lo com a mãe para a zona livre governada pelo marechal Pétain, pois temia que o neto fosse perseguido pelos ocupantes nazistas. Os judeus franceses - ou franceses judeus - da época enxergavam o regime de Vichy como um possível refúgio em face da sanha persecutória nazista. O tempo mostraria que estavam iludidos a este

\footnotetext{
${ }^{56}$ Entretien avec Marc Ferro: guerre et images de guerre. Temps des Médias. Revue d'Histoire, n. 4, Paris: Nouveau Monde, 1/2005, p. 239-251. DOI: 10.3917/tdm.004.0239. Disponível em: http:// www.cairn.info/revue-le-temps-des-medias-2005-1-page-239.htm.

${ }^{57}$ STIVE, Dany. Marc Ferro, de la défaite du Vercors à la liesse victorieuse dans Lyon libéré. $L^{\prime} H u-$ manité. Paris, 04/08/2014. Disponível em: http://www.humanite.fr/marc-ferro-de-la-defaitedu-vercors-la-liesse-victorieuse-dans-lyon-libere-548775.
} 
respeito, quando Vichy se dobrou de vez aos alemães, no final de 1942. A mãe de Marc acabou deportada e gaseada pelo III Reich, não se sabe em qual campo de extermínio. Quanto ao avô, não sabemos.

Marc seguiu os estudos em Grenoble, ocupada pelos italianos, e ali iniciou a formação universitária em História e Geografia. Em 1944, sob a ameaça de ser recrutado pelo STO alemão, como muitos amigos, optou por ingressar na Resistência. David Stives informa que Ferro tinha grande capacidade de precisar, em mapas, o movimento das tropas resistentes ou inimigas, razão pela qual atuou na inteligência do Vercors. Conhecimento especial da geografia.

O jovem Marc participou da luta contra os alemães e integrou a tropa que liberou Lyon, em 2 de setembro de 1944. Segundo Ferro, o batalhão de 200 homens contou com grande apoio popular, circundou "a cidade, em marcha, por duas ou três vezes, para criar a ilusão de que os resistentes eram mais numerosos $(\ldots)^{\prime \prime}{ }^{58}$

Durante décadas, Marc Ferro jamais comentou seus atos na Resistência. Perguntado por Anne-Claude Rendu sobre a razão de tal silêncio, Ferro disse que preferiu evitar o que ouvia, no Vercors, dos ex-combatentes da Grande Guerra, ${ }^{59}$ sempre jactantes, acrescentando que nunca quis se valer desses atos na juventude para prosperar na carreira de historiador: "poderia ser acusado de usar minha atuação na Resistência para disputar e alcançar títulos universitários (...)".60

É verdade que se poderia questionar, também aqui, como um resistente do Vercors pôde prosseguir tranquilamente seus estudos em Grenoble e, ao mesmo tempo, atuar na Resistência. Haveria nisto um leve odor de construção de memória similar a de vários historiadores de sua geração. Mas o testemunho de Ferro parece mais credível. Nunca destacou a sua atuação na Resistência, embora nela tenha atuado sem dúvida; tampouco escreveu um livro sobre o assunto, sobre o que foi questionado na entrevista de 2005. Historiador do século XX, um dos maiores; combatente discreto, um dos

\footnotetext{
58 "Une fois, deux fois, trois fois... pour faire nombre, donner l'illusion que nous étions nombreux alors que nous ne devions pas être plus de 200!".

59 Assim como Girardet, malgré lui même, para quem os membros da AF eram insuportáveis, Marc Ferro considerava os veteranos da Grande Guerra do mesmo modo. Afirmou que eles se jactavam do passado combatente, dizendo "moi, Monsieur, j'ai fait la guerre". Ferro rejeitava aquela atitude dos veteranos, quando lutou em armas contra a ocupação. A isto atribui a omissão, por anos, de sua participação no Vercors. Cf. Entretien avec Marc Ferro, op. cit., nota 45.

60 Idem.
} 
menores. Ferro apenas mencionou a sua ação, décadas depois da guerra, detalhando-a, sem bravatas.

\section{III - O paradigma da memória construída no pós-guerra: Marc Bloch}

Os relatos dos historiadores franceses analisados até aqui, cuja consolidação profissional data do pós-1945, variou bastante, desde a forjadura de um perfil resistente em face da ocupação alemã até a "confissão" de colaboração, nem tanto com a ocupação, senão com o regime de Vichy.

No caso de Ariès não havia como contornar os atos de colaboração na juventude com o governo do marechal Pétain. Entre os que alegaram participação na Resistência, é possível elencar vários motivos, desde o patriotismo ao horror de serem recrutados pelo STO. O mais importante neste caso, porém, parece residir numa combinação de fatores relacionados ao engajamento político de cada um no pós-guerra e às escolhas "politicamente corretas" para dar seguimento à carreira de historiadores.

A maioria dos que se disseram resistentes quando jovens assumiram posições de esquerda no pós-guerra, alguns como militantes do Partido Comunista Francês. Todos passaram por conjunturas políticas dilacerantes, como a crise do gaullismo nos anos 1960; a questão da descolonização africana, com destaque para a guerra argelina; o desalento com o regime soviético provocado pelas denúncias de Khrushchev, após a morte de Stalin em 1953.61

Por ora, vale a pena registrar que os dilemas políticos vivenciados pelos historiadores em foco se entrelaçaram, por vezes de modo dramático, com as escolhas que deviam fazer em termos acadêmicos, nem tanto do ponto de vista teórico ou temático, senão institucional.

Basta dizer que, no pós-1945, não somente a revista Annales foi restaurada como o movimento historiográfico francês inaugurado por Febvre e Bloch alcançou o status de École des Annales. A revista, em si, foi rebatizada como Annales d'Histoire Sociale em 1945, e logo no ano seguinte como Annales. Économies, Sociétés, Civilisations. Em 1994, adotou o título ora vigente de Annales. Histoire, Sciences Sociales.

O historiador-mor do pós-guerra foi, como se sabe, Fernand Braudel, primus inter pares da historiografia francesa depois da morte de Febvre. Brau-

\footnotetext{
${ }^{61}$ Nikita Khrushchev (1894-1971) foi secretário geral do Partido Comunista da URSS (1953-1964). Ao assumir o governo, denunciou os massacres e os expurgos ordenados por Stalin.
} 
del nunca foi comunista, nem mesmo de esquerda, embora tenha aberto posições no meio acadêmico francês a historiadores marxistas, porque economicistas, a exemplo de Pierre Vilar. Mas o que mais importa, em nosso caso, é relembrar que Fernand Braudel foi prisioneiro de guerra dos alemães desde 1940 e, portanto, tratado como herói no meio dos historiadores, após a libertação. Braudel herdou, de certo modo, a "aura antinazista" de Marc Bloch, este sim resistente, fuzilado pelo ocupante alemão em 1944.

Bloch, por sua vez, se transformou em um ícone, no pós-1945, não só da historiografia "revolucionária" dos Annales como do próprio combate contra a ocupação alemã. Os historiadores franceses que então se assumiram como de centro-esquerda iniciaram suas carreiras profissionais em meio à sacralização da memória de Bloch.

O próprio Bloch, porém, sequer sonhava com tal monumentalização, quer antes da guerra, quer, muito menos, na clandestinidade da Resistência. Diplomado nos anos 1920 tornou-se um grande medievalista, reconhecido pela publicação de Les rois thaumaturges em 1924. Um grande historiador entre muitos outros. Lecionou anos na Universidade de Estrasburgo, nos anos 1920, que naquele tempo era periférica no meio acadêmico francês. À diferença de Febvre, Bloch fracassou, entre 1928 e 1935, nas tentativas de ingressar no Collège de France. Destacou-se, é verdade, pela fundação da revista Annales de Histoire Économique et Sociale, juntamente com Febvre em 1929, mas esta, nos anos 1930, era apenas uma dentre várias revistas francesas de Ciências Humanas.

Quanto à imagem de combatente, certamente pesou a seu favor o fato de ter lutado nas trincheiras da Primeira Guerra a partir de 1915, chegando ao posto de capitão. Deixou preciosos depoimentos sobre a sua atuação na Grande Guerra, em correspondência com o filho Étienne Bloch, entre outros. Voluntariou-se, também, para lutar no exército francês quando da declaração de guerra à Alemanha, em 1939, apesar de seus 53 anos de idade àquela altura. Era o mais velho dos oficiais de segundo escalão no exército francês e viveu de perto a acachapante derrota, consumada no armistício de 22 de junho de 1940. Tentou retomar a sua carreira, após a derrota, lecionando na Universidade de Estrasburgo, transferida para Clermont-Ferrand desde 1939. Recebeu convite da Fundação Rockfeller para lecionar na New School (Nova York) em 1941, mas só admitiu emigrar caso pudesse levar a família inteira (nove pessoas), o que foi negado pelo consulado norte-americano em Lyon. Transferiu-se para Montpellier em 1942, onde atuou por alguns meses apenas. Em novembro de 1942, a ocupação militar de Vichy pelos alemães tornou insustentável a segurança dele e da família. Abandonou a docência, 
a família dispersou-se. Em 1943, senão antes, tornou-se membro ativo da Resistência em Lyon.

Em recente tese de doutorado, Jougi Guimarães Yamashita discorreu sobre a construção do personagem Marc Bloch, no pós-1945, como exemplo de grande cidadão francês: historiador monumental e, ao mesmo tempo, militante antinazista, homem que ofereceu a própria vida em sacrifício pela honra da França. ${ }^{62}$ É nisto que reside o nó de nossa questão para discutir as lembranças da guerra relatadas pelos historiadores da Nova História. O modelo de historiador e de combatente: Marc Bloch.

O grande mérito da obra de Yamashita, em termos documentais, reside no cotejo do que Bloch escreveu sobre si ou do que outros escreveram sobre ele com a correspondência que Bloch manteve com diversos interlocutores durante a guerra, mormente com seu filho primogênito, Étienne Bloch. Yamashita abre um caminho luminoso para se conhecer de que modo a figura de Marc Bloch foi transformada em monumento. Desafia a memória construída pelos historiadores franceses do pós-guerra, sem desmerecê-la, o que nos permite compreender melhor as razões pelas quais tantos se esforçaram em pontuar sua adesão à Resistência no tempo da guerra quando jovens, enquanto outros, por terem militado no lado oposto, não tiveram saída senão admitir a posição assumida.

Mas quem iniciou a construção do personagem/monumento? O próprio Bloch, de certa maneira, contribuiu para isto em textos escritos nos anos da guerra, só publicados postumamente, em especial A estranha derrota, escrita entre julho e setembro de 1940, publicada em 1946. "S3 "Serão estas páginas um dia publicadas?" - eis como Bloch iniciou a apresentação do texto cujo destino era tão incerto quanto o dele próprio. Bloch confiou o manuscrito ao geógrafo Philippe Arbos que o escondeu na casa de um amigo comum, Pierre Canque, em Clermont-Ferrand. Este, por sua vez, enterrou o manuscrito em sua propriedade em Orcines, temeroso de que pudesse ser descoberto em uma das batidas policiais, cada vez mais frequentes no fim da guerra.

Trata-se de um texto precioso que, com toda a razão, embora tardiamente, foi amplamente reconhecido como obra de referência para o estudo sobre a derrota francesa. Nos dois primeiros ensaios (Apresentação do testemunho e $O$

\footnotetext{
${ }^{62}$ YAMASHITA, Jougi Guimarães. As guerras de Marc Bloch: nacionalismo, memória e construção da subjetividade. Tese de doutorado em História Social, Universidade Federal Fluminense, Niterói, 2015.

${ }^{63}$ BLOCH, Marc. A estranha derrota. Rio de Janeiro: Jorge Zahar, 2011. A obra foi mais difundida somente a partir da quarta edição, na coleção Folio da Gallimard, em 1990.
} 
depoimento de um vencido), Bloch combina o seu testemunho pessoal, como capitão do exército, com uma análise cirúrgica da estratégia, da tática e da logística militares francesas diante do rolo compressor alemão. No derradeiro ensaio, Exame de consciência de um francês, Bloch arrisca-se a explicar as razões da derrota. Critica a III República, a politicagem parlamentar, a imprevidência diante do rearmamento alemão. No tocante às lutas sociais, Bloch critica o sindicalismo francês por ter defendido a redução de horas de trabalho em momento crítico, bandeira incorporada pela Frente Popular sob o comando de Léon Blum, francês de origem judaica como ele e grande líder socialista.

A estranha derrota foi o penúltimo livro de Bloch, ao qual se seguiu o Apologie pour l'histoire, escrito por volta de 1941, que deixou incompleto, e só publicado em 1949. Fracassando em todas as tentativas de ajustamento, aderiu à Resistência, como vimos, atuando na inteligência do Franc Tireurs até ser preso e fuzilado.

A consagração de Bloch como historiador em conexão com seu martírio enquanto herói da Resistência foi inventariada na citada tese de Yamashita, As guerras de Marc Bloch. O primeiro passo da consagração foi dado logo em 1944, por iniciativa de Febvre, que noticiou seu fuzilamento no sexto número da Mélanges. Logo no primeiro número do pós-guerra, em 1945, quando a revista foi restaurada com o nome de Annales d'Histoire Sociale, Febvre assinou, em 1945, o artigo "Marc Bloch: de l'histoire au martyre", um necrológio em grande estilo, em que a excelência do Bloch historiador é relacionada à sua coragem patriótica. Em 1954, Febvre publicou "Marc Bloch: dix ans après", um balanço laudatório que saiu nos Annales. Economies, Societés, Civilisations. Entrementes, Febvre publicou, em 1949, a primeira edição de Apologie por l'histoire, baseado em três rascunhos (dentre aos cinco redigidos por Bloch). ${ }^{64}$

Construiu-se, na França, um conceito (legitimador) do ofício de historiador, no qual Marc Bloch - sua obra, sua vida - funcionava como modelo ideal. Um modelo que combinava expertise acadêmica com cidadania patriótica. Os historiadores franceses de que tratamos acima construíram suas carreiras segundo a maior ou menor adequação a este modelo. Alguns avançaram com rapidez. Outros foram marginalizados por décadas, como Ariès. A construção deste modelo seguiu, pari passu, a construção de certa memória que realçava, de vários modos, a atitude combativa dos franceses em face da ocupação alemã. Como se a resistência datasse de 1940. Como se, desde o

\footnotetext{
${ }^{64}$ Apologie foi reeditada na França desde 1952, ganhando fôlego em 1974, prefaciada por Georges Duby.
} 
início, a maioria dos franceses tivesse rejeitado a ocupação nazista e o regime de Vichy. Como se o apoio ao regime, na época, fosse coisa de minorias oportunistas e colaboracionistas.

\section{IV - Desconstrução do mito da Resistência e seu impacto entre os historiadores franceses}

Este modelo foi posto em xeque, como vimos no início, quando estreou o documentário de Marcel Orphüls, em 1971, Le chagrin et la pitié. Filmado em 1969, reconstruiu a história da França ocupada por meio de imagens de época entrelaçadas com depoimentos de pessoas de origem social e opção política muito diferentes, quando não opostas, que tinham vivido a experiência da ocupação. Propôs uma visão radicalmente distinta daquela contada desde a libertação. Multiplicou evidências de que os franceses, longe de resistir desde 1940, haviam se ajustado à nova ordem, agiram como colaboradores ou, quando menos, se mantiveram indiferentes. ${ }^{65}$

O xeque-mate na memória da França resistente, já o dissemos, veio com o livro de Robert O. Paxton, Vichy France, ${ }^{66}$ traduzido para o francês em 1973. ${ }^{67}$ Paxton sustentou que Vichy não foi apenas um fantoche da Alemanha nazista, senão o próprio Estado francês reformulado. Demonstrou que o regime, além de colaborar com os ocupantes, pretendeu associar seu projeto de revolução nacional à nova ordem nazista na Europa, apoiado por elites sobretudo agrárias, valorizadoras de tradições regionais, da hierarquia, do catolicismo. Destacou o enorme apoio popular de que desfrutava o regime e o grande prestígio do marechal Pétain naqueles anos. O impacto provocado pelo livro de Paxton ficou conhecido como revolução paxtoniana, ${ }^{68}$ e inspirou

\footnotetext{
${ }^{65} \mathrm{O}$ fato de ser um documentário com imagens, fatos e personagens adensa a veracidade da narrativa, como se imparcialidade e objetividade fossem inerentes ao gênero documentário. O impacto do filme foi tamanho que o governo francês proibiu a sua exibição na TV durante dez anos (liberado pelo governo Mitterrand, em 1981). Para análises críticas do documentário ver ROUSSO, Henry. Le syndrome de Vichy de 1944 à nos jours. $2^{\mathrm{a}}$ edição. Paris: Seuil, 1990; LABORIE, Pierre. Le chagrin et le venin. La France sous l'occupation, mémoire et idées recues. Montrouge: Bayard, 2011.

${ }^{66}$ PAXTON, Robert O. Vichy France. Old guard and new order. 1940-44. Nova York: Knopf, 1972.

${ }^{67}$ A edição francesa vendeu apenas 12 mil exemplares, entre 1973 e 1985. A partir de então a divulgação cresceu, alcançando o apogeu nos anos 1990, em meio aos processos contra os colaboracionistas Paul Touvier (1994) e Maurice Papon (1997). Cf. WIEDER, Thomas. La France de Vichy. Le Monde, 08.08.2008. Disponível em: http//www.lemonde.fr/livres/article/2008/08/08/ la-france-de-vichy-par-thomas-wieder_1081586_3260.html.

${ }^{68}$ Sobre a revolução paxtonienne ver FISHMAN, Sarah et al. (org.). La France sous Vichy: autour de Robert O. Paxton. Paris/Bruxelas: CNRS/Éditions Complexe, 2004.
} 
diversos estudos de pesquisadores dedicados à história contemporânea ou ao tempo presente.

A primeira vítima da revolução paxtoniana, por assim dizer, foi Lucien Febvre, cuja atuação entre 1940 e 1944 foi objeto de reprovação, ainda que discreta, no imediato pós-guerra. A divulgação do livro de Paxton na França estimulou a explicitação de um ressentimento que vinha de longe. Febvre foi acusado de mudar o nome da revista para um anódino Mélanges, aceitando pressões nazistas; de ter convencido Bloch a abandonar a coeditoria porque, sendo judeu, estava impedido de assumir tal posto, segundo as leis da ocupação; de não ter feito sequer um ato substantivo, durante a guerra, a favor do amigo e parceiro de muitos anos.

Em 1981, Alain Guerreau sugeriu que, se Febvre não era pró-nazista, "a hipótese de um Lucien Febvre pura e simplesmente pétainista parece aceitável". ${ }^{69}$ Em 1994, o livro de Philippe Burrin ${ }^{70}$ traçou as coordenadas do debate. Febvre foi enquadrado entre os "acomodados": não chegava a ser colaborador, mas nunca enfrentou o regime de Vichy nem a ocupação alemã. No ano seguinte, o jornal Le Monde levantou a questão: "deveríamos queimar Lucien Febvre?". No mesmo ano, apareceram artigos com títulos polêmicos: "Lucien Febvre, inferior a si mesmo?" (Le Monde) ou "Falsa querela em torno de Lucien Febvre" (L'Histoire). Mas tal polêmica, inspirada no dilema resistência versus ocupação ou, por vezes, entre esquerda versus direita, adensou a mitificação de Bloch e a condenação de Febvre. O historiador Peter Schötler demonstrou os equívocos desta interpretação. ${ }^{71}$

Nos ensaios de ego-história publicados em 1987, bem como nas entrevistas e autobiografias que se estendem dos anos 1990 aos primeiros anos do atual século, jamais se aludiu à revolução paxtoniana, como se os historiadores da Nova História, preferencialmente dedicados aos estudos sobre Idade Média e Antigo Regime, ignorassem, por opção, o intenso debate sobre o comportamento dos franceses durante a ocupação. Esta

\footnotetext{
${ }_{69}$ Apud YAMASHITA, Jougi Guimarães, op. cit., p. 271.

${ }^{70}$ BURRIN, Philippe. La France à l'heure allemande. Paris: Seuil, 1994.

${ }^{71}$ SCHÖTTLER, Peter. Marc Bloch et Lucien Febvre face à l'Allemagne nazie. Genèses, n. 21, Paris, Berlim, 1995, p. 75-95. O historiador alemão questionou o contraste maniqueísta entre Febvre e Bloch, baseado na correspondência entre os historiadores antes e durante a guerra, bem como em textos publicados por eles, quer nos Annales, quer nas Mélanges. Sugere que Febvre era mais incisivo do que Bloch na denúncia do perigo nazista, antes da guerra. Demonstra que, em várias conferências no Collège de France, ele condenou a ocupação, por meio de metáforas. Cita Marleen Wessel, para quem Febvre atuava em um maquis de la parole.
} 
é uma hipótese que somente não valeria para René Rémond e Marc Ferro, especialistas na história do século XX. Acaso estes últimos não poderiam ser reconhecidos como autores da Nova História francesa? Ora, Rémond é considerado uma referência para a nova história política. Quanto a Marc Ferro, ninguém menos do que Le Goff, perguntado se aquele era um historiador da escola dos Annales, respondeu: "historiador completo, que captou perfeitamente o espírito dos Annales". Ato contínuo acrescentou: "filho de um bancário israelita, a mãe não retornou da deportação, sobrevivente do Maquis do Vercors, atuante na libertação de Lyon (...)".72

De modo que todos os historiadores analisados são integrantes da terceira geração dos Annales que viveu experiências diversas quando jovens no tempo da ocupação alemã. Impossível desconsiderar os depoimentos tortuosos, na maioria dos casos, quando não a omissão deliberada de fatos, particulares ou gerais, vividos naqueles anos.

O impacto da revolução paxtoniana foi enorme, ainda que implicitamente, na construção desses relatos. Ela explica, talvez, o empenho da maioria em ligar o próprio passado, nos anos da guerra, a atitudes de resistência ou mesmo ao ingresso nas organizações armadas; explica, ainda, o empenho dos vichystas em justificar suas escolhas nos anos da ocupação, alegando razões de família ou arroubos da juventude; pode mesmo explicar o longo silêncio de Marc Ferro, estudioso renomado da história do século XX, que combateu no Vercors.

A revolução paxtoniana implicou, no campo historiográfico - neste caso de forma explícita -, um revisionismo de grande alcance. ${ }^{73}$ Em seguida, vários historiadores passaram a questionar o binômio resistência/colaboração, como se uma ou outra fossem as únicas opções possíveis no tempo da ocupação. Conforme este binômio, que passou a moldar a reconstrução da identidade nacional, o legítimo cidadão francês era o resistente ou, quando menos, o simpatizante ou apoiante da luta. Em contrapartida, os que serviram ao regime de Vichy ou o apoiaram foram estigmatizados como colaboradores, traidores da França.

O revisionismo historiográfico, acentuado nos anos 1990, conduziu à conclusão de que a memória de resistência na França ocupada era um mito a ser desconstruído.

Um excelente exemplo desta desconstrução, no campo historiográfico, encontra-se em um artigo de Jean-Pierre Azéma, publicado em livro de ho-

\footnotetext{
${ }^{72}$ LE GOFF, Jacques. Uma vida para a história. Tradução. 2a edição. São Paulo: Unesp, 2007, p. 197.

73 Sobre a polêmica historiográfica europeia, sobretudo francesa, ver ROLLEMBERG, Denise. Resistência. Memória da ocupação nazista na França e na Itália. São Paulo: Alameda, 2016.
} 
menagem a René Rémond, falecido em 2007. Azéma, um dos grandes especialistas dos anos troubles, observa a discrição com que Rémond se referiu ao período em que viveu na zona livre, bem como a temas envolvendo Vichy. ${ }^{74}$ Ao comentar a entrevista de 1976, Azéma sublinha que Rémond "não disse sequer uma palavra sobre suas reações a respeito do que ele chama de "os inícios do regime de Vichy",75 limitando-se a realçar que aquela fase lhe proporcionou valiosa experiência política.

Já na qualidade de historiador, ressalta Azéma, Rémond não ignorou os tais "inícios do Estado francês, nem podia ignorá-los. Tanto é que, em 1970, organizou o colóquio O governo de Vichy e a revolução nacional (1940-42), reunindo testemunhas da época e historiadores. A coletânea dos textos do colóquio saiu em 1972, ${ }^{76}$ que Azéma considerou "audaciosa, cautelosa e problemática". Audaciosa, porque personagens de Vichy tiveram voz no evento. Cautelosa, porque a cronologia adotada pelo colóquio fixou o marco final exatamente no ano em que Pierre Laval, colaboracionista assumido, retornou ao ministério de Vichy como chefe de governo. Problemática, porquanto não programou qualquer comunicação sobre a exclusão, tampouco sobre a repressão aos comunistas, aos defensores do regime destituído, aos franco-maçons ou a judeus.

Ainda em 1970, lembra Azéma, o colóquio organizado foi alvo de crítica feroz de Henri Michel, que se recusou a dele participar. Membro da SCFIO (Seção Francesa da Internacional Operária) desde 1934, resistente ativo durante a ocupação alemã, diretor do Comitê de História da Segunda Guerra Mundial, criado em 1951, Henri Michel argumentou, então, que "a operação (colóquio) visava a banalizar e, portanto, a reabilitar Vichy". ${ }^{77}$

Em 1990, por ocasião de outro congresso, organizado por Jean-Pierre Azéma e François Bédarida, Vichy e os franceses, Rémond justificou a ausência daqueles temas fulcrais no colóquio de 1970. Na introdução que redigiu para a coletânea dele resultante, afirmou que “...na época esses aspectos não tinham, ao olhar da consciência coletiva, tomado a importância que

\footnotetext{
${ }^{74}$ AZÉMA, Jean-Pierre. L'historien et Vichy. In: JEANNENEY, Jean-Noël \& SIRINELLI, Jean-François (dir.). René Rémond historien. Paris: Presses de Sciences Politiques, 2014. Azéma não usou o testemunho dado a Alya Aglan em sua avaliação, mas somente o depoimento dos Ensaios de ego-história e a entrevista concedida a Aimé Savard em 1976. Não saberíamos explicar por que, já que o próprio Azéma escreveu o prefácio do livro de Alya Aglan, publicado em 1994: AZÉMA, Jean-Pierre. Préface. In AGLAN, Alya, op. cit., 1994.

${ }^{75}$ AZÉMA, Jean-Pierre, op. cit., 2014, p. 125.

${ }^{76}$ RÉMOND, René (org). Le gouvernement de Vichy et la révolution nationale. Paris: Armand Colin, 1972.

77 AZÉMA, Jean-Pierre, op. cit., 2014, p. 126.
} 
têm atualmente".78 Azéma outra vez criticou a "justificativa" de Rémond, argumentando que "o historiador não pode ser uma simples ressonância da consciência coletiva". ${ }^{79}$ Citou, como prova, a obra do citado Henri Michel, Vichy année 1940, publicada ainda em 1966, na qual dedicou um capítulo aos "párias" do regime. ${ }^{80} \mathrm{E}$ foi além, acrescentando que tampouco na sua obra maior, Les droites en France, mesmo na edição de 1982, Rémond nada disse sobre as exclusões e perseguições do regime de Vichy. Considerando que "Rémond nunca demonstrou qualquer antissemitismo", afirma Azéma, "essa ocultação dos primeiros tempos de Vichy é um enigma". ${ }^{81}$

Elegância de Azéma, ao falar em "enigma". Afinal, trata-se de um texto incluso em obra de homenagem a René Remond. Em todo caso, a crítica de Azéma a Rémond confirma a análise que fizemos dos relatos de Rémond sobre a guerra, em perspectiva comparada. Entre omissões e relatos sinuosos, Rémond permite entrever, para dizer o mínimo, que no início da guerra ele era simpatizante do regime de Vichy ou, certamente, um admirador de Pétain. O depoimento oferece pistas valiosas a este respeito, como a defesa de Carcopino, ex-ministro de Vichy, e a condenação de Pierre Laval, como se o regime, sem Laval, fosse legítimo para Rémond. ${ }^{82}$

Mas não é o caso, aqui, de julgar Rémond ou qualquer outro historiador pelas opções políticas no tempo da juventude, senão o de submeter os textos memorialísticos sobre os anos da guerra à crítica histórica, como bem recomendou Marc Bloch em sua Apologie.

Neste sentido, a melhor reflexão de conjunto para entendermos tais vacilações encontra-se nos trabalhos de Pierre Laborie, a quem recorremos

\footnotetext{
${ }^{78}$ René Rémond apud AZÉMA, Jean-Pierre, op. cit., 2014, p. 126.

7 AZÉMA, Jean-Pierre, idem, ibidem, 2014, p. 126-7.

${ }^{80}$ MICHEL, Henri. Vichy année 40. Paris: Robert Laffont, 1966. De fato foi tardia a preocupação dos contemporâneos da Segunda Guerra com a deportação perpetrada pelos nazistas e colaboracionistas. Mesmo no interior da Resistência, a questão da perseguição aos judeus era lateral ou desprezada. Momento de inflexão na opinião pública mundial a esse respeito ocorreu em 1961, com o julgamento de Adolf Eichmann, oficial da SS responsável pelas deportações de civis, sobretudo judeus, durante a guerra.

${ }^{81}$ AZÉMA, Jean-Pierre, op. cit., 2014, p. 127.

${ }^{82}$ No artigo "L'historie des droits", Michel Winock observou que Rémond não considerou, em sua tipologia das direitas francesas, a vertente surgida nos anos 1880, nacionalista, antissemita, xenófoba. Afirma que foi essa "tradição nova" que inspirou as perseguições perpetradas por Vichy. Nas edições seguintes do livro de Rémond, a revolução nacional foi "associada apenas ao exercício do poder sob Vichy". Em 1992, em Français sous Vichy, "ele não hesita mais em oferecer um julgamento relativamente severo sobre o regime tomado em sua globalidade". In: AZÉMA, Jean-Pierre, op. cit., 2014, p. 128.
} 
de início, et pour cause. Em artigo de 1997, Laborie considerou que a ideia de resistência francesa esteve por anos marcada por mitologias e heroísmos, entusiasmos cândidos e teorizações estéreis. ${ }^{83}$ Mas foi além. Inspirado em Primo Levi, conhecido escritor italiano que sobreviveu a Auschwitz, ${ }^{84} \mathrm{La}^{-}$ borie sugeriu que a maioria dos franceses vivenciou os anos da ocupação e de Vichy de maneira ambivalente, entre apoio e rejeição, conforme as circunstâncias. É o que o autor definiu como um modo de pensar-duplo, capaz de abrigar escolhas opostas. A maioria dos franceses vivia nesta zona cinzenta, território onde as convicções eram frágeis, ambíguas e incertas:

Os franceses, em sua maioria, não foram primeiramente vichistas depois resistentes, pétainistas, depois gaullistas, mas puderam ser, simultaneamente, durante um tempo mais ou menos longo, e de acordo com os casos, um pouco dos dois ao mesmo tempo. ${ }^{85}$

Laborie propõe uma interpretação que cai como luva em nossa análise de alguns expoentes da Nova História. Jovens estudantes, no início dos anos 1940, estavam antes de tudo engajados na sua formação universitária. Ainda não eram, longe disso, os historiadores que viriam a ser. Nos anos da guerra, analisados os depoimentos, pode-se dizer que, em grande parte, estavam inseridos na zona cinzenta definida por Laborie para pensar os franceses em geral. Indecisos entre a acomodação e a colaboração. Alguns inclinados a resistir, afirmaram uns, mas, diríamos nós, tal disposição foi estimulada pela ameaça de recrutamento pelo STO, quando não pelo desembarque dos Aliados na Normandia, em junho de 1944. Cinzentos, portanto. Marc Ferro foi o mais resistente dentre os aqui analisados e, também, o mais discreto e tardio ao comentar a sua participação.

Os historiadores examinados neste artigo, quando jovens, eram na maioria cinzentos. O que contaram tem mais a ver com a trajetória deles no pós-1945 do que com suas ações durante a guerra. Tem mais a ver com a memória do que com a história. Memória oficial, vale repetir. É nisto que reside o eventual interesse deste artigo, ao tratar de autores que, jovens no

\footnotetext{
${ }^{83}$ LABORIE, Pierre. L'idée de Résistance, entre définition et sens: retour sur un questionnement. In: Idem. Les Français des années troubles. De la guerre d' Espagne à la Liberation. Paris: Seuil, 2003, p. 67. Publicado em 1998, em Cahiers de L'IHTP, com o título "La Résistance et les Français, nouvelles approches", número especial, dez. 1997.

${ }^{84}$ Cf. LEVI, Primo. Os afogados e os sobreviventes. Rio de Janeiro: Paz e Terra, 1990 [original, 1986].

${ }^{85}$ LABORIE, Pierre. 1940-1944. Os franceses de pensar-duplo. In: ROLLEMBERG, Denise $\mathcal{E}$ QUADRAT, Samantha Viz (org.). A construção social dos regimes autoritários, vol. 1: Europa. Rio de Janeiro: Civilização Brasileira, 2010, p. 39.
} 
tempo da ocupação, protagonizaram uma autêntica revolução historiográfica nas últimas décadas do século XX.

\section{Referências bibliográficas}

AGLAN, Alya. Mémoires résistantes. Histoire du Réseau Jade-Fitzroy. Paris: Éditions du Cerf, 1994.

ARIÈS, Philippe. Um historiador diletante. Rio de Janeiro: Bertrand Brasil, 1994.

BLOCH, Marc. A estranha derrota. Rio de Janeiro: Jorge Zahar Editor, 2011.

BOSI, Ecléa. Memoria e sociedade: lembranças de velhos. 2 volumes. São Paulo: Edusc, 1987.

BURKE, Peter. A Revolução Francesa da historiografia: a Escola dos Annales. São Paulo: Unesp, 1991.

BURRIN, Philippe. La France à l'heure allemande. Paris: Seuil, 1994.

CAMARGO, Aspásia. O historiador e a história: um relato de François Furet. Estudos Históricos, vol. 1, n. 1, Rio de Janeiro: FGV-CPDOC, 1988, p. 143-161.

COMPTE, Bernard. Une utopie combattante. L'École des Cadres d'Uriage. 1940-1942. Paris: Fayard, 1991.

DUBY, Georges. A historia continua. Rio de Janeiro: Jorge Zahar Editor, 1993.

FISHMAN, Sarah et al. (org.). La France sous Vichy: autour de Robert O. Paxton. Paris/ Bruxelas: IHTP/CNRS/Éditions Complexe, 2004.

JEANNENEY, Jean-Noël \& SIRINELLI, J-François (org.). René Rémond historien. Paris: Presses de Sciences Politiques, 2014.

LABORIE, Pierre. Historiens sous haute surveillance. Esprit, n. 198, 1994, p. 36-49. Les Français des années troubles. Paris: Seuil, 2003.

. Le chagrin et le venin. La France sous l'Occupation, mémoire et idées recues. Montrouge: Bayard, 2011.

1940-1944. Os franceses do pensar-duplo. In: ROLLEMBERG, Denise $\mathcal{E}$ QUADRAT, Samantha Viz (org.). A construção social dos regimes autoritários. Legitimidade, consenso e consentimento no século $X X$, vol. 1: Europa. Rio de Janeiro: Civilização Brasileira, 2010.

LE GOFF, Jacques $\mathcal{E}$ NORA, Pierre (org.). Faire de l'histoire. Paris: Gallimard, 1974. . Uma vida para a história. Tradução. São Paulo: Unesp, 2007.

LEVI, Primo. Os afogados e os sobreviventes. Rio de Janeiro: Paz e Terra, 1990.

MICHEL, Henri. Vichy année 40. Paris: Robert Laffont, 1966.

NORA, Pierre (org.). Essais d'ego-histoire. Paris: Gallimard, 1987.

PAXTON, Robert O. Vichy France. Old guard and new order. 1940-44. Nova York: Knopf, 1972.

ROLLEMBERG, Denise E Q QUADRAT, Samantha (org.). A construção social dos regimes autoritários, vol. 1: Europa. Rio de Janeiro: Civilização Brasileira, 2010.

ROLLEMBERG, Denise. Resistência. Memória da ocupação nazista na França e na Itália. São Paulo: Alameda, 2016.

RÉMOND, René. La droit en France de 1815 à nos jours. Paris: Aubier, 1954. 
Colin, 1972.

(org.). Le gouvernement de Vichy et la révolution nationale. Paris: Armand

ROUSSO, Henry. Le syndrome de Vichy de 1944 à nos jours. 2a edição. Paris: Seuil, 1990. SCHÖTTLER, Peter. Marc Bloch et Lucien Febvre face à l'Allemagne nazie. Genèses, n. 21, Paris, 1995, p. 75-95.

STIVE, Dany. Marc Ferro, de la défaite du Vercors à la liesse victorieuse dans Lyon libéré. L'Humanité. Paris, 04/08/2014. Disponível em: http://www.humanite.fr/marcferro-de-la-defaite-du-vercors-la-liesse-victorieuse-dans-lyon-libere-548775.

WIEDER, Thomas. La France de Vichy. Le Monde, Paris, 08/08/2008. Disponível em: http//www.lemonde.fr/livres/article/2008/08/08/la-france-de-vichy-par-thomas-wieder_1081586_3260.html.

YAMASHITA, Jougi Guimarães. As guerras de Marc Bloch: nacionalismo, memória e construção da subjetividade. Tese de doutorado em História Social. Universidade Federal Fluminense. Niterói, 2015.

Recebido: 15/10/2016 - Aprovado: 19/06/2017 